\title{
The Architectural Illusion of Edoardo Tresoldi: The Reconstruction of the Basilica of Siponto
}

\author{
By Francesco Del Sole
}

\begin{abstract}
The Ministry of Tourism commissioned Edoardo Tresoldi in 2016 to restore the Basilica of Siponto (Puglia, Italy), of which only ruins remain. The project is obtained through metal wefts that intertwine in the air presumably reconstructing the original environments: it is an example of creative restoration. This essay aims to examine the genesis of this artwork that has rekindled the debate on the usefulness of this type of restoration, introduced for the first time by Cesare Brandi (1906-1988) and Renato Bonelli (1911-2004) who gave rise to a critical discussion on the role that restoration must play in reconstructing the original spaces of a lost monument. Creative restoration tends to include in the concept of "restoration" all those actions of reconstruction necessary to restore "truth" to the lost monument in order to guarantee its enjoyment, making the "evocative fantasy" take over. Faced with an architecture that has now lost its face, the added value of Tresoldi's creative restoration will be highlighted, which is not only the reconstruction of the Basilica but the possibility, through the wire mesh that generates transparency, to understand the monument not only as a historical document but as an artwork that needs to be experienced aesthetically, safeguarding the genius loci, making the site a place to be rediscovered in its link with the territory.
\end{abstract}

\section{Introduction}

In September 2013, the Regional Direction for the Cultural and Landscape Heritage of Apulia published a public notice in "Gazzetta Ufficiale" for the realization of the "works of recovery and enhancement of the Archaeological Park of Siponto (restoration and enhancement of the early Christian basilica; restoration and enhancement of the two levels of the Romanesque church etc.)." ${ }^{\text {1 }}$ The task would be entrusted to the young artist Edoardo Tresoldi who, assisted by historians, archaeologists and architects, would create the project entitled "Where Art Reconstructs Time", an installation obtained through metal wefts that intertwine in the air, reconstructing the presumably original rooms of the now disappeared early Christian basilica, complete with columns, capitals and trusses, defined in terms of plan and dimensions on the basis of strictly philological criteria. As such, the new basilica of Tresoldi has a weight of 14 tonnes, due to the 4500 metres of double galvanised welded mesh. The work of the artist's young

\footnotetext{
*Assistant Professor, Department of Cultural Heritage, University of Salento, Italy.

1. "Gazzetta Ufficiale della Repubblica Italiana - $5^{\circ}$ Serie Speciale - Contratti Pubblici n. 110 del 18-9-2013 - MIBAC - Direzione regionale per i beni culturali e paesaggistici della Puglia Bando di gara CIG: 53013826D1". The project was carried out with structural funds from the Interregional Operational Programme. Cultural, natural and tourism attractions - P.O. In. 20072013. It is possible to consult the full text of the public notice at the site: https://www.gazzettauf ficiale.it/.
} 
team, with an average age of 25 years, lasted approximately five months and was inaugurated with great enthusiasm in the initial days of March 2016. ${ }^{2}$ Importantly, we are not dealing with a simple work of contemporary art; the Apulian institution, when describing the technical details of the public contract, uses very precise terms: it had to be a restoration and enhancement of the site. The choice to give life to this contemporary experiment can certainly be considered brave, but a vital position as well within the debate on the nature of architectural restoration, in this case, applied to a strategic archaeological site. ${ }^{3}$

\section{The Early Christian Basilica of Siponto: Historical Hints}

Located on the slopes of the Gargano peninsula, Siponto was born as a Roman colony around $194 \mathrm{BC}$. Abandoned between the $4^{\text {th }}$ and $5^{\text {th }}$ centuries A.D. following repeated looting, was reborn under the aegis of Christianity when freed from invaders. ${ }^{4}$ Presumably around 465 A.D., the Gran Duomo Sipontino was built, which later took the name of Basilica di Santa Maria Maggiore. Accordingly, a renovation work of the following century enriched the basilica with valuable mosaic floors, of which some traces remain. The church thus acquires the splendour that makes it an obligatory stop for pilgrims from continental Europe, passing through Rome, to Siponto before continuing on to the Gargano sanctuaries and embarking from the ports of Apulia to Jerusalem. The plan of the early Christian Basilica consists of three naves separated by columns with a raised

2. Some reflections have already been written on the Edoardo Tresoldi's artwork in Siponto: P. Pierotti and A. Nonni, Dove l'arte ricostruisce il tempo. Il parco archeologico di Santa Maria di Siponto. Un modello di valorizzazione a Manfredonia (Roma: PPAN - Comunicazione e networking per il costruito, 2016); G. De Felice, "Cathedrals in the Desert: a Review of Edoardo Tresoldi's Installation at Siponto, Italy” Public Archeology 15, no. 1 (2016): 59-61; E. Chiavoni, F. Porfiri and G. L. Tacchi, "La rappresentazione dell'assenza: reinterpretare la storia attraverso un linguaggio contemporaneo," in Territori e frontiere della rappresentazione, Atti del $39^{\circ}$ Convegno internazionale dei docenti delle discipline della rappresentazione - Napoli, 14-16 Settembre 2017 (Roma: Gangemi, 2017), 829-834. A quotation from Siponto's artwork can be found in L. Wong, Adaptive reuse: extending the life of buildings (Basel: Birkhäuser, 2017), 226-239. It is possibile to find various interviews with the artist or reviews of the artwork: C. Ezechieli, "Spazio e materia. Conversazione con Edoardo Tresoldi. Labics, due progetti per due concorsi" ioArch 13 (July 2019): 60-63; M. Jonna, "Edoardo Tresoldi- Le infinite forme dell'invisibile" Icon Design (November 2018), 112-119; M. De Lucchi, "Contamination. Hybridisation” Domus 1027 (September 2018): 38-39; E. Giorgi, "Edoardo Tresoldi, l'uomo che ha stregato il mondo (e Forbes) con le sue cattedrali metalliche," in La Repubblica, 15 May 2017; J. Mairs, "Edoardo Tresoldi uses wire mesh to reconstruct ancient Roman church in Italy," in Dezeen, 6 April 2016.

3. An important text to consult in order to take stock of the policies adopted in the field of restoration is V. Cazzato, Istituzioni e politiche culturali in Italia negli anni Trenta (Rome: Istituto Poligrafico dello Stato, 2001).

4. Studies on the history of Siponto and its artistic and architectural masterpieces are powerful. I will limit myself here to mention some relatively recent ones: M. S. Calò Mariani, "L'arte medievale e il Gargano," in La montagna sacra. S. Michele, Monte Sant'Angelo, il Gargano (Foggia: Congedo, 1991), 56-72; M. Fabbri, "La basilica paleocristiana di Siponto: nuove acquisizioni," Vetera Christianorum 31 (1994): 189-196; O. Giuffreda, Antologia storico-artistica di Siponto, Manfredonia, Monte Sant'Angelo (San Marco in Lamis: CRSEC FG/29, 2005); C. Lagagnara, Siponto - Archeologia di una città abbandonata nel medioevo (Foggia: Grenzi, 2011). 
central apse. The early Christian basilica probably remained in function until the 11th century and was the object of rehashing by Archbishop Leone (1023-1050). Moreover, the archbishop himself promoted-adjacent to the early Christian building - the construction of a new square basilica with two apses, a jewel of Apulian Romanesque architecture. Unlike the Romanesque counterpart, only the foundations of the early Christian basilica - which over time has become a pile of ruins - have been preserved. The old town was then finally evacuated in 1223, when King Manfred of Swabia founded the New Siponto, now Manfredonia. Only centuries later, the discovery of a pillar and an altar in 1872 dedicated to the goddess Diana rekindled interest in the aforementioned and gave rise to a series of reliefs that allowed us to outline the overall layout of the site. From the observation of the stratifications, the portion of the wall made of opus reticulatum emerged distinctly, which must, in fact, have included a very large environment then hidden by the building of the cathedral's naves. Furthermore, the elevation of the apse in tiles and bricks would have been instead retraced to the original architecture of the Basilica, since it was built with the same technique. Consequently, there is no doubt that the poor state of conservation of the finds is largely due to the obstinacy with which natural disasters and sieges struck the territory (see Figure 1).

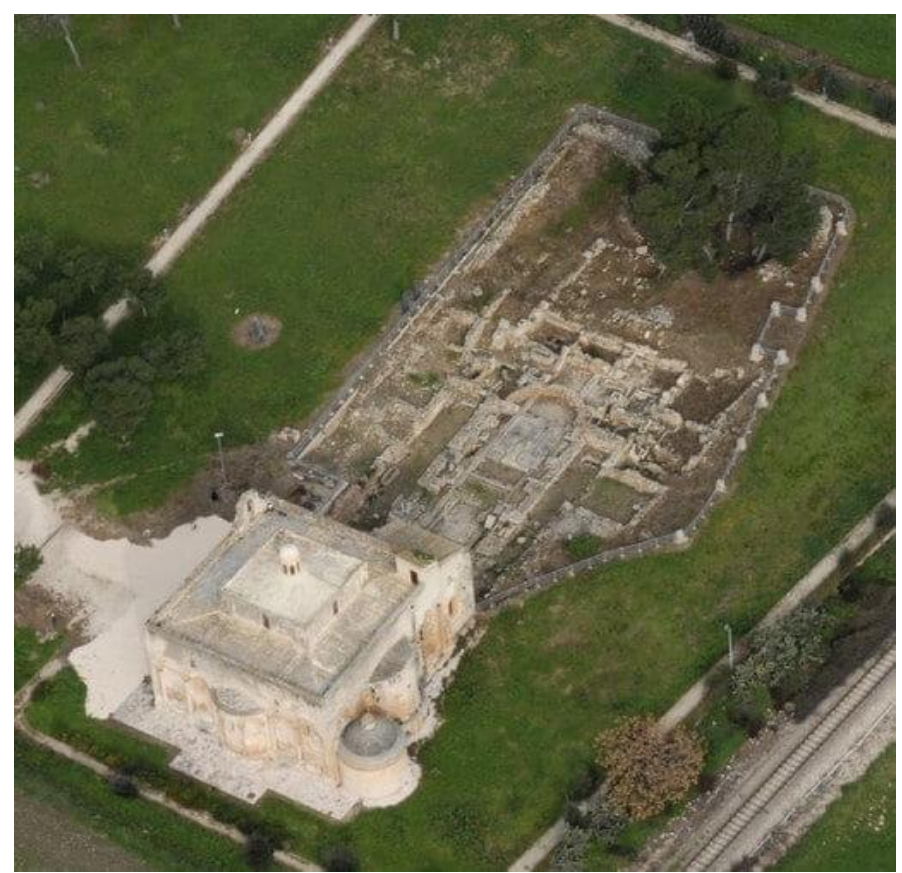

Figure 1. The Siponto's Archaeological Park before the Intervention of Edoardo Tresoldi

Source: Wikimedia Commons. 


\section{The Creative Restoration of Edoardo Tresoldi (Utilitas)}

The reconstruction of Tresoldi recalls the last phase of the ancient factory. At first, a careful study of the ancient parts was carried out, allowing the realization of a preliminary survey for the restoration; then the consolidation of the wall structures was carried out. The installation was implemented on sacrificial surfaces placed above the ancient structures that protected the crests of the walls and allowed Tresoldi's work to not interfere with the monument while ensuring its reversibility. Previously, the monument had lost its face and the ideal reconstruction of the sacred space was the prerogative of a few scholars. As such, the architectural approach aimed to identify with a common visitor who finds himself in an archaeological area where the mere presence of masonry structures makes it difficult to understand the third dimension. As a result - intended as an active enhancement of the monument - the restoration was necessary. Beyond the various theories on architectural restoration, a basic concept is common to every vision: man, with his intervention, must tend to preserve the architectural significance of a monument. ${ }^{5}$ The usefulness of Tresoldi's work is to be found precisely in the attempt to propose an innovative action of protection which, in the wake of Alois Riegl's teachings (1858-1905), must not miss the opportunity to propose renewed alliances between conservation and innovation, ensuring that the results of historical research are useful for the enjoyment of the work by a wide public. ${ }^{6}$ Currently, we are rather distant from that decadent devotion of Camillo Boito (1836-1914), who, in the wake of John Ruskin (1819-1900), highlighted the right of ancient monuments to sleep undisturbed in their last sleep, hoping for a sort of religious preservation of the relics in their state of abandonment (his definition of "stupendous filth" is famous.) ${ }^{7}$ Gustavo Giovannoni (1873-1947)

5. On the architectural restoration and the theories that have followed one another from the nineteenth century onwards, within the abundant bibliography on the subject, see in particular: S. Scarrocchia, Alois Riegl - Il culto moderno dei monumenti (Bologna: Nuova Alfa, 1990); A. Riegl, "The modern cult of monuments: its character and origin," Oppositions 25 (Fall 1982): 21-51; M. Andaloro, La teoria del restauro nel Novecento da Riegl a Brandi, Atti del Convegno internazionale di studi, Viterbo, 12-15 Novembre 2003 (Firenze: Nardini 2006); G. Carbonara, Trattato di restauro architettonico (Torino: Utet, 1996); S. Casiello, La cultura del restauro. Teorie e fondatori (Venezia: Marsilio, 1996); P. Marconi, Materia e significato. La questione del restauro architettonico (Bari: Laterza, 1999); R. Amore, A. Pane and G. Vitagliano, Restauro, monumenti e città. Teorie ed esperienze del Novecento in Italia (Napoli: Electa, 2008); L. Vlad Borrelli, Conservazione e restauro delle antichità. Profilo storico (Roma: Viella, 2010); L. Galli, Restauro architettonico: letture dai maestri (Milano: Hoepli, 2016); G. Cristinelli, Fondamenti per una dottrina del restauro architettonico (Roma: Ginevra Bentivoglio, 2017); P. C. Pellegrini, Manuale del riuso architettonico: analisi ed interventi contemporanei per il recupero degli edifice (Palermo: Flaccovio, 2018). On methodologies see S. Franceschi and L. Germani, Manuale operativo per il restauro architettonico. Metodologie di intervento per il restauro e la conservazione del patrimonio storico (Roma: Tipografia del Genio Civile, 2005).

6. Famous is his phrase: "What value does the entire cultural heritage have if experience does not unite us to it?", in Scarrocchia, Alois Riegl - Il culto moderno dei monumenti (Bologna: Nuova Alfa, 1990), 22. All references to Riegl's theories on architectural restoration are taken from this edition of Scarrocchia, which edited the Italian translation.

7. "The monument is a book, which I intend to read without reductions, additions or rehashes. I want to feel very sure that everything written in it came out of the pen and style of the author" in P. 
would reaffirm the importance of a restoration even "scientifically imperfect, which represents a lost record of the history of architecture, rather than the complete renunciation of the monument." accepted since the Athens Charter of 1931-because it is a simple reconstruction with the original materials of the monument itself - the problem arose when it was considered necessary to add missing parts for an effective restoration. The following provisions over the years (from the Instructions for the Restoration of Monuments of 1938, to the Venice Charter of 1964, up to the Restoration Charter of 1972) are in marked contrast to the false antique, openly condemning it and reaffirming the principle that "restoration must stop where the hypothesis begins" (art. 9.) ${ }^{9}$ However, the Venice Charter itself, the fundamental pivot of modern restoration theories, states in the same article: "in terms of conceptual reconstruction, any work of completion, recognized as indispensable for aesthetic and technical reasons, must be distinguished from architectural design and must bear the mark of our times. The restoration will always be preceded and accompanied by a historical and archaeological study of the monument". With regard to the insertion of new elements, considered necessary starting from a critical judgement of value, these will have to guarantee the harmony between old and new as well as showing "not to be ancient works, but to be works of today. The above is in accordance with the principle of "modern discrimination of additions" elaborated by Boito long before. ${ }^{10}$ Roberto Longhi (1890-1970) proposed, in 1940, the idealist conception of the mental restoration of the lost monument as a modality that the restorer must implement in order to propose a restoration of the image without touching the remaining ruins, as if it were a visual

Marconi, Materia e significato. La questione del restauro architettonico (Bari: Laterza, 1999), 203. See C. Boito, "I restauri in architettura. Dialogo primo," in Questioni di pratiche di belle arti (Milano: 1893). For studies on Boito see A. Grimoldi, Omaggio a Camillo Boito (Milano: Franco Angeli, 1991); S. Casiello, La cultura del restauro. Teorie e fondatori (Venezia: Marsilio, 1996), 145-164; G. Stolfi, "Boito, gli altri e il moderno pensiero sul restauro," in Quaderni dell'Istituto di Storia dell'Architettura. Saggi in onore di Renato Bonelli (ed.) C. Bozzoni, G. Carbonara, G. Villetti (Roma: Multigrafica, 1992), 935-942; L. Vlad Borrelli, Conservazione e restauro delle antichità. Profilo storico (Roma: Viella, 2010), 185-194.

8. Gustavo Giovannoni (1873-1947) is "pupil" and Boito's heir with regard to the concept of restoration. Engineer, he dedicated himself to the study and restoration of architecture: in the 20s and 30s he promoted the first Faculty of Architecture in Rome, where he established the Chair of Architectural Restoration, which he held until his death. See G. Giovannoni, Il restauro dei monumenti (Roma, 1945); S. Casiello, La cultura del restauro. Teorie e fondatori (Venezia: Marsilio, 1996), 267-290; L. Vlad Borrelli, Conservazione e restauro delle antichità. Profilo storico (Roma: Viella, 2010), 191-193.

9. Venice Charter (1964), art. 9; The International Charter of Restoration (known as the Venice Charter) was promulgated at the conclusion of the Second International Congress of Architects and Technicians of Historic Monuments held in Venice from 25 to 31 May 1964.

10. "Excluding in fact the act of imitation (equal matter), not being able to grant an exclusively material differentiation (which could turn the intervention into an act of competition), operating with the intention of establishing instead with the original chromatic fabric of reference an identity of effect, just using the colors that will converge there will result that it will be appropriately 'in relation' with the original, 'equal and at the same time differentiated' and 'neutral' to the expressive potential of the work on which therefore will not interfere in any way altering", in U. Baldini, Teoria del restauro e unità di metodologia (Firenze: Nardini, 1981). 
correction, conducted "almost exclusively with museum techniques."," This reflection was followed by other theories of scholars, such as Cesare Brandi (1906-1988), who spoke of "legitimate secretion of the image," Bonelli (1911-2004), who proposed a critical restoration that must make use of the evocative imagination "to recompose the missing parts or reproduce the hidden ones and finally find the complete unity of the work." " From this debate, therefore, the definition of "creative restoration" was born, a type of restoration useful to restore "truth" to the lost monument in order to guarantee its enjoyment, understood not only as a historical document but as a work of art that needs to be experienced aesthetically. Experts and scholars in the field of architectural restoration, such as Giovanni Carbonara, took Edoardo Tresoldi as a model, who, with his creative restoration, brings art and architecture back to being democratic, ensuring that a "prudential restoration" also goes hand in hand with the comprehensibility, for a wide public of early Christian architecture. ${ }^{14}$ In accordance with the above, Carbonara recalls how, especially in recent times, no artist has distinguished himself for similar operations in the restoration of a monument. ${ }^{15}$ In the past, some "revolutionary" architects have proposed similar forms of restoration, such as Franco Minissi (1919-1966) and Franco Ceschi, making transparency the key element to enhance the landscape where "the artistic wonders" of the site are located ${ }^{16}$ (see Figure 2).

11. G. Carbonara, op. cit., I, p. 56. Roberto Longhi's article on the themes mentioned is R. Longhi, "Restauri," in La Critica d'Arte 2, 1940.

12. C. Brandi, Teoria del restauro (Torino: Einaudi, 1977), 74. English version: C. Brandi, Theory of restoration (Firenze: Nardini, 2005).

13. R. Bonelli, "Restauro (il restauro architettonico,)" in Enciclopedia Universale dell'Arte XI. Venezia-Roma: Istituto per la Collaborazione Culturale 1963.

14. Giovanni Carbonara, in the report held in Venaria as part of the International Conference "Sustainable Restoration Value. Constellation of Comparisons on Restoration" promoted on 25 February 2016, takes up the notion of creative restoration, one of the pivots of Roberto Pane and Renato Bonelli's theories: "Restoration is a way of making criticism and making history, not expressed verbally but translated into action. We work on the material work and not on its conception, we do not act on copies as in literature, poetry and music, but always and only on unique and unrepeatable originals, and for this we need better and better professionalism and more and more refined techniques that reduce the invasiveness of the intervention, that guarantee reversibility and compatibility. The integration of artwork and restoration leads to that creative restoration that can reintegrate great gaps". Text available on the site: http://www.ppan.it/stories/va lore-restauro-sostenibile-carbonara-porta-a-venaria-il-modello-siponto-con-l-opera-d-arte-di-tresol $\mathrm{di} /(10 / 06 / 2020)$.

15. The need to integrate, in the discipline of restoration, the attention to "matter" and "image" is recalled in the theories of Longhi, Brandi and Bonelli cited below.

16. "In the '50s and '60s Franco Minissi in Villa del Casale in Piazza Armerina has created a metal roof as a landscape element, denotative of the ancient space and ancient volumes. In Veio, in the '90s, Franco Ceschi virtually reconstructed the Temple of Apollo, an Etruscan work that was reduced to a few centimetres from the ground, reproducing its height with steel rods", in P. Pierotti and A. Nonni, Dove l'arte ricostruisce il tempo. Il parco archeologico di Santa Maria di Siponto. Un modello di valorizzazione a Manfredonia (Roma: PPAN - Comunicazione e networking per il costruito, 2016), 21. Carbonara had already mentioned in 1996 the "revolutionary restoration" of Minissi in Sicily, recalling Brandi's support for the project: "In this regard, a reflection on the proposals, still very topical, put forward more than thirty years ago by Brandi for the excavations of Piazza Armerina in Sicily proves to be very timely. [...] The scholar, having examined various 


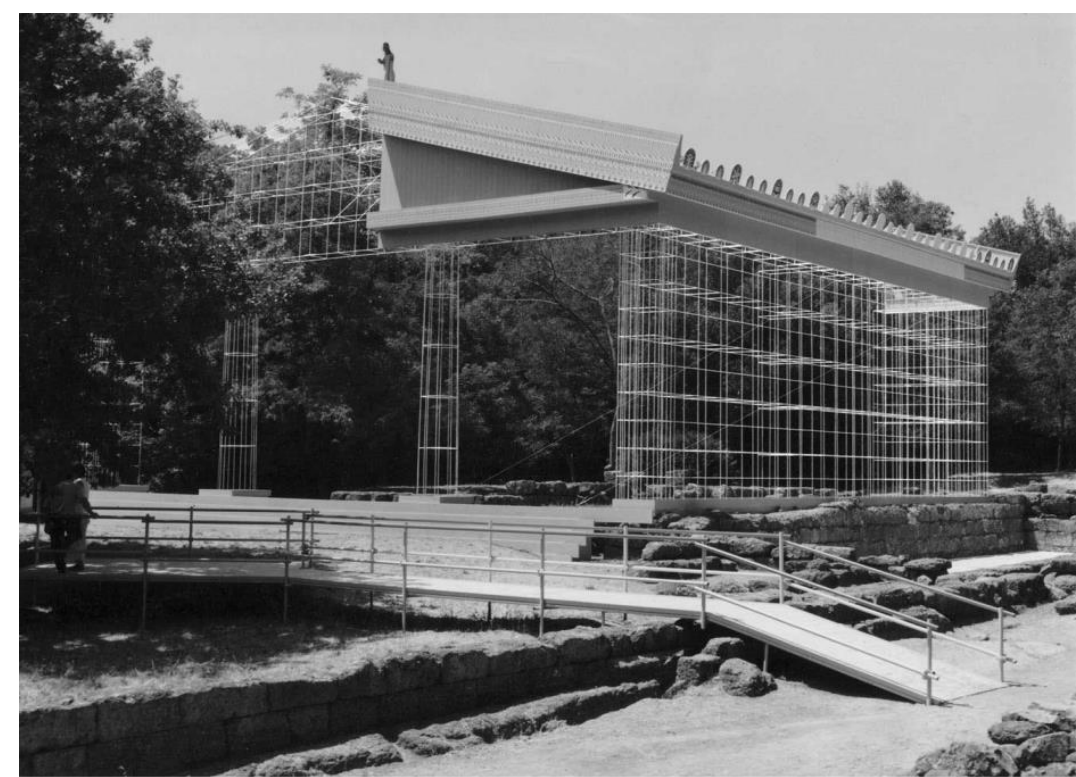

Figure 2. Franco Ceschi, Partial Reconstruction of the Temple of Apollo, 1992, Portonaccio (Veio, Italy)

Source: Wikimedia Common.

\section{The Material and Transparency: Protection of the Genius Loci (Firmitas)}

With the work Incipit, presented in 2015 as part of the contemporary art exhibition "Meeting del Mare", Tresoldi introduced the public to the archetype of the absolute vision that would soon be accomplished with the installation of Siponto. On that occasion, the artwork was a declaration of intent and represented a true manifesto of the mechanism of deployment of the "Materia Assente" applicable to the architectural project. Moreover, Incipit represented the original aspect of a form entrusted to the imagination of the spectator in relation to the landscape (see Figure 3). Tresoldi brings back to Siponto this transparent, almost illusory architecture, present in terms of volume and absent in terms of material. The importance of the use of a new material - the wire mesh that generates transparency, a characteristic element of the intervention-is to be found in the renewed concept of protection that derives from the most recent reflections on restoration.

solutions, including traditional ones, expressed his appreciation for the one which, with the help of a 'light and transparent material' proved to be 'entirely modern and entirely modest'; an idea which was then concretised by Franco Minissi's genius. [...] The site [...] is to be saved in its rural charm and protected as the 'artistic wonders', the villa and the famous mosaics it contains", in G. Carbonara, Trattato di restauro architettonico (Torino: Utet, 1996), 1, 48. Brandi's writing referred to in Carbonara's text is Brandi, "Archeologia siciliana" Bollettino dell'Istituto Centrale del Restauro (1956), 27-28. On the problem of restoration and types to be applied in archaeological areas see M. C. Laurenti, Le coperture delle aree archeologiche. Museo aperto (Roma: Gangemi, 2006). 


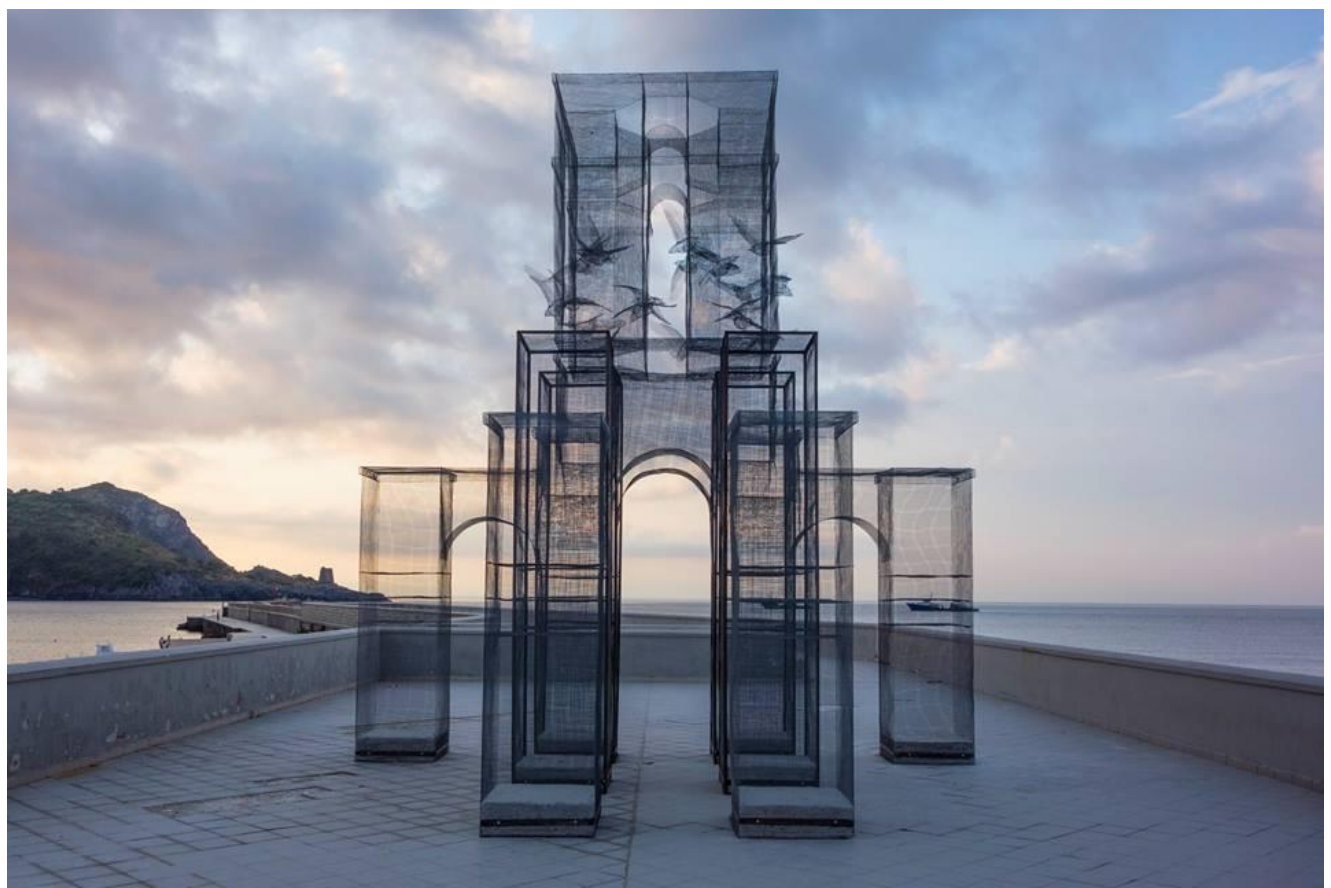

Figure 3. Edoardo Tresoldi, Incipit, 2015, Meeting del Mare Marina di Camerota, Italy

Source: Fabiano Caputo, 2015.

The Krakow Charter of 2000 is the last stage of the discussion on the subject at an international level (later transposed in 2004 by the Italian Code of Cultural Heritage and Landscape in Italy); not only a very important step appears institutionalized - which provides for the application of the principles of restoration no longer to the individual architectural monument but to the entire built heritage - but also a concept of protection that includes all the unbuilt landscape areas, since it is the entire territory that preserves important elements of human history and culture. In drawing up the public call for proposals, the Regional Direction for Apulia proposed a dialogue between archaeology and contemporary art that is part of an overall vision of landscape understood in its complexity, between architectural evidence of the past and the present, following that intentional value as a memory that allows today's man a conceptual restoration of architecture, visually representing the idea of the time elapsed since its construction (see Figures 4-5). The contemporary value of this architecture is expressed by respecting the original use value of the basilica, safeguarding the sacrosanctity of the place, albeit in new forms, and re-introducing the site into the tourist circuit of the Gargano with the aim of intercepting even the religious pilgrimage. At the same time, it is important to ensure the necessary value of novelty that stimulates curiosity and attention to the monument even by those who are not experts, and - through the artistic value of the installation - can imagine the original form of the sacred place. ${ }^{17}$ It is, as Anna Mattirolo says, "a happy

17. "The courageous choice of the public commission has made this experimentation possible, investing in innovation and creative industry to carry out the restoration and redevelopment of the existing ancient structures, with the aim of re-introducing them into the tourist circuit of the 
mental disorientation between two historical times." 18 Accordingly, the monument does not become past but is always kept alive, and it is possible, as the Granada Convention (1985) states, "to enhance the preservation of the architectural heritage in public opinion both as an element of cultural identity and as a source of inspiration and creativity for present and future generations." 19 The material used by Tresoldi becomes a means to protect not only the archaeological ruins but also the landscape in which they are immersed, giving it a scenic value as if it were a theatrical backdrop designed to experience the basilica, thereby safeguarding the genius loci, making the site a place to be rediscovered in its link with the territory. ${ }^{20}$ The installation shuns any further sign that is not of nature. The apsidal basin, for example, is no longer a space to contain the altar and the Eucharistic tabernacle, but creates a new bond with the Pinus Halepensis behind it, a secular and distinctive species of the territory of Foggia. Thus, far from its history but never from the place that welcomes it today, the grey nudity of the structure reveals a different sacredness, no longer religious but rather having always resided in the landscape. Tresoldi's artwork exploits the neutrality of space and the use of architectural archetypes as well as transforms the contradiction generated in the encounter between the artificiality of the square mesh and the naturalness of the landscape. "Incorporated, not restored, it is pure ruin, it becomes a source of information, as it contains the imprints of time, in the same way as a beautiful wrinkled face." Now, in its entirety "is, ultimately, present",21 (see Figures 6-8). Resultantly, a few years later, the Regional Direction's bet is won: the archaeological park of Siponto is one of the most visited places in the region with arrivals from all over the world.

Gargano, intercepting also the religious pilgrimage". The quote comes from the press kit distributed by the Regional Management on the occasion of the inauguration of the work. Text available on the site: http://puglia.beniculturali.it/index.php?it/406/santa-maria-di-siponto-dove-larte-ricostruisce-iltempo (10/06/2020). Giovanni Carbonara is also of the same opinion: "Tresoldi's proposal [...] is open to comprehensibility even for those who do not have a specific culture, it recovers the high and reproduces the third dimension", Pierotti and Nonni, Dove l'arte ricostruisce il tempo. Il parco archeologico di Santa Maria di Siponto. Un modello di valorizzazione a Manfredonia, 2016, 21.

18. Ibid, 17.

19. "Convention for the Protection of the Architectural Heritage of Europe" (Granada Convention), 1985, art.15;

20. "A place is a space which has a distinct character. Since ancient times the genius loci, or 'spirit of place', has been recognized as the concrete reality man has to face and come to terms with in his daily life. Architecture means to visualize the genius loci, and the task of the architects to create meaningful places, whereby he helps man to dwell", in C. Norberg-Schulz, Genius Loci (Milano: Electa, 1979), 5.

21. A. Ugolini, Ricomporre la rovina (Firenze: Alinea, 2010), 17. 




Figure 4. Edoardo Tresoldi, Siponto, Early Christian Basilica, Detail of the Creative Restoration by Edoardo Tresoldi in relation to the Ruins of the Basilica Source: Roberto Conte, 2016.

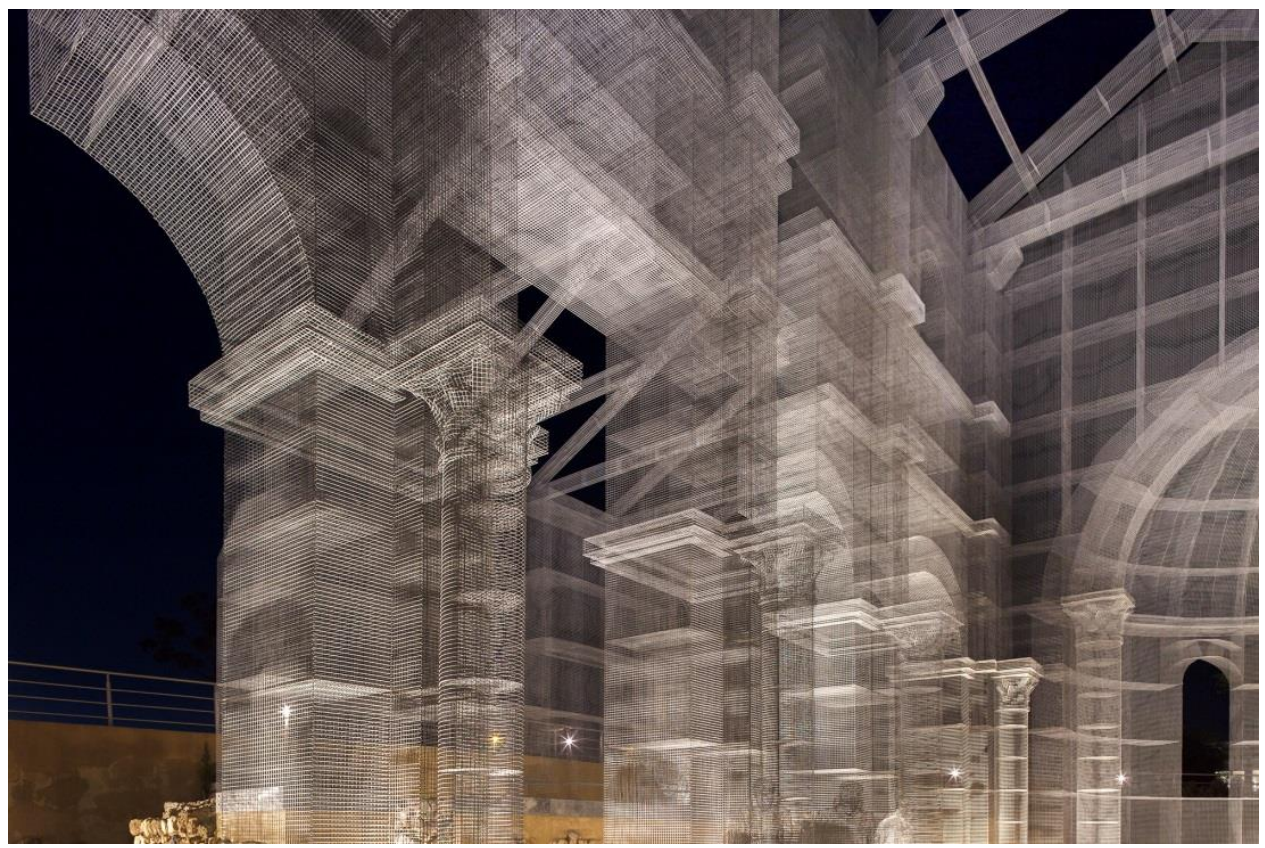

Figure 5. Edoardo Tresoldi, Siponto, Early Christian Basilica, Detail of the Column and Capital in Metal Wefts

Source: Roberto Conte, 2016. 

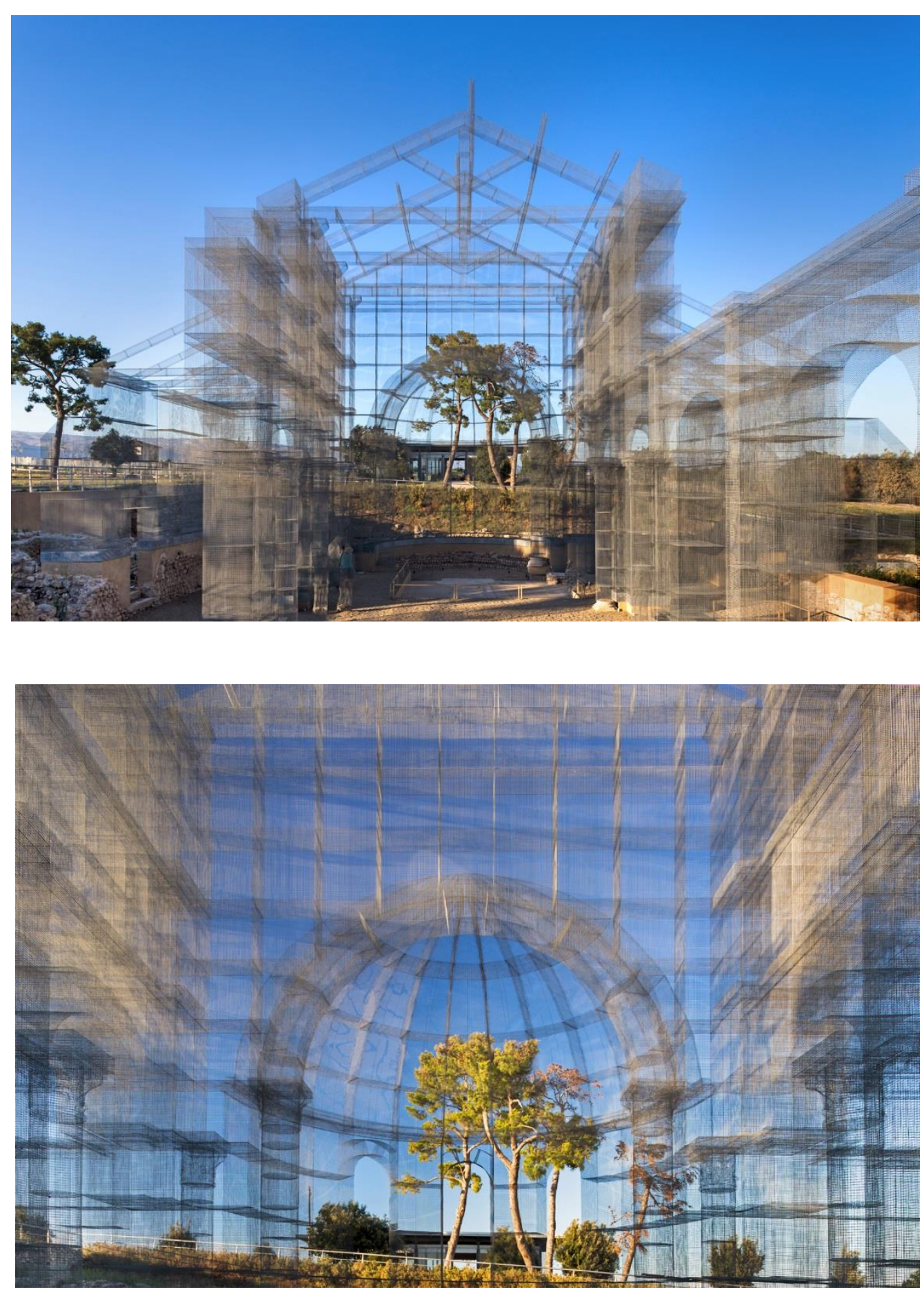




Figures 6-8. Edoardo Tresoldi, Siponto, Tresoldi's Artwork in its Relationship with the Surrounding Landscape

Source: Roberto Conte, 2016.

\section{Metaphysical Ruin (Venustas)}

Edoardo Tresoldi, indicated by Forbes magazine as one of the most influential "under 30 " in the world, ${ }^{22}$ is very shy in his way of intervening space. His architecture is a filter, fitting into the context without pretending to become the main attraction itself. The primary objective is to capture the essence of the place by celebrating the dialogue between the different elements and man, building spaces that allow to be reached. The rhythms of transparency generate amplified points of view while the light and atmospheric factors determine its readability in ever-changing situations. His works have been defined as aesthetic or even poetic architectures; they aim to arouse amazement, succeeding in drawing in the air and allow the user to see the sky beyond a "dome". These are precisely the criteria for the public contract drawn up by the Regional Direction, hoping for a restoration project aimed at "emotional and sensorial involvement." 23 It is precisely through the evocation of the lost parts that an architectural object can be brought back to life, which aims to build a bridge with the past through such a game of volumes. In the artist's conception, the work becomes fully inserted in the cycle of the 2020].

22. See: https://www.forbes.com/profile/edoardo-tresoldi/\#3e675bf23461. [Accessed 10 June

23. "Gazzetta Ufficiale della Repubblica Italiana - $5^{\circ}$ Serie Speciale - Contratti Pubblici n. 110 del 18-9-2013 - MIBAC - Direzione regionale per i beni culturali e paesaggistici della Puglia Bando di gara CIG: 53013826D1". The project was carried out with structural funds from the Interregional Operational Programme. Cultural, natural and tourism attractions - P.O.In. 2007-2013. It is possible to consult the full text of the public notice at the site: https://www.gazzettaufficiale.it/ 
monument, becoming a real metaphysical ruin. Following his reasoning, from the encounter between man's project (form) and matter, the architectural act is born; then the abandonment takes over, a phenomenon that starts the dynamic process of alteration and decomposition of the place, the state of ruin: matter disintegrates and enriches itself with its temporal experience due to the inexorable action of nature. This gradual metamorphosis slowly leads the monument to disappearance. The metaphysical ruin comes into play as a further stage of the life cycle; it tells about the encumbrances and languages of the original architecture, rekindling the memory and proposing a real concatenation of remains, but at the same time, it accompanies the visitor towards an authentic emotional experience of the space contaminating itself with the surrounding landscape. The language of transparency proposes a new monument, a "path to act," to be experienced from different angles, deeply distinct from the mere contemplation of ruin. In the young artist's vision, his aesthetic architectures are the means to tell contrasts and temporal symbiosis, absorbing the landscape itself, contributing to bring back the sacredness of the site to life.

\section{Conclusions}

The basilica of Siponto is now an "open work". On purpose, Tresoldi's team has limited itself to the reconstruction of the first three bays of the main nave (see Figures 9-10). This indeterminacy allows each visitor to fill in the missing parts, stimulating evaluations and questions. In order to understand the new basilica of Siponto, it is necessary to intuit the aesthetic value of a new architecture that aims to make the objectivity of a historical document accessible to a vast public, articulated in a wise interweaving of subjectivity and objectivity "so as to obtain a work that is both modern and ancient at the same time, somehow new but also totally and authentically original, working on the double register of the poetic and the diacritic." ${ }^{24}$ The greatest reflection that the experiment conducted at Siponto proposes is the hypothetical (and provocative) ideal continuation of the concept introduced by Article 9 of the Venice Charter: "Restoration must stop where the hypothesis begins: where restoration does not arrive, the imagination can."

24. Carbonara, op. cit., I, 56. 


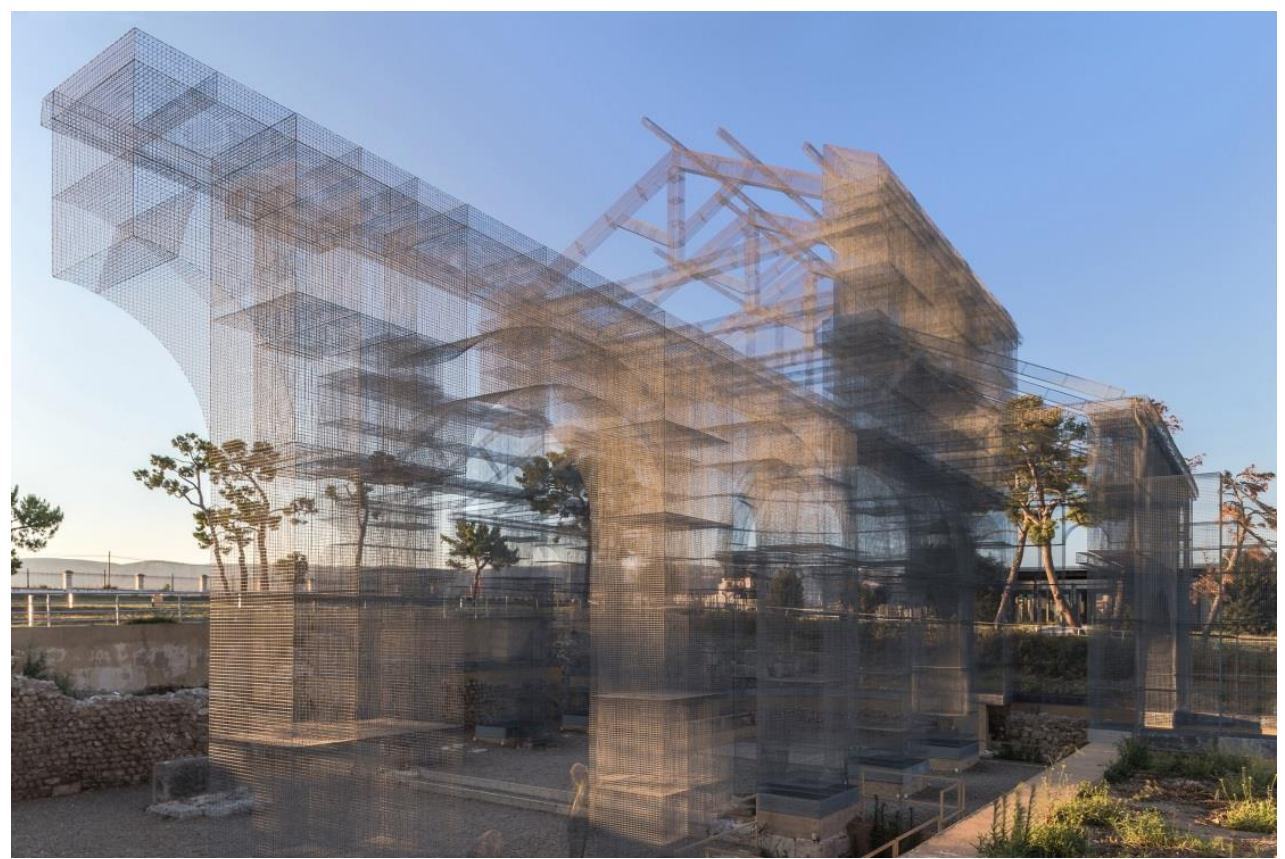

Figure 9. Edoardo Tresoldi, Siponto, View of the Nave Left Unfinished Source: Roberto Conte, 2016.

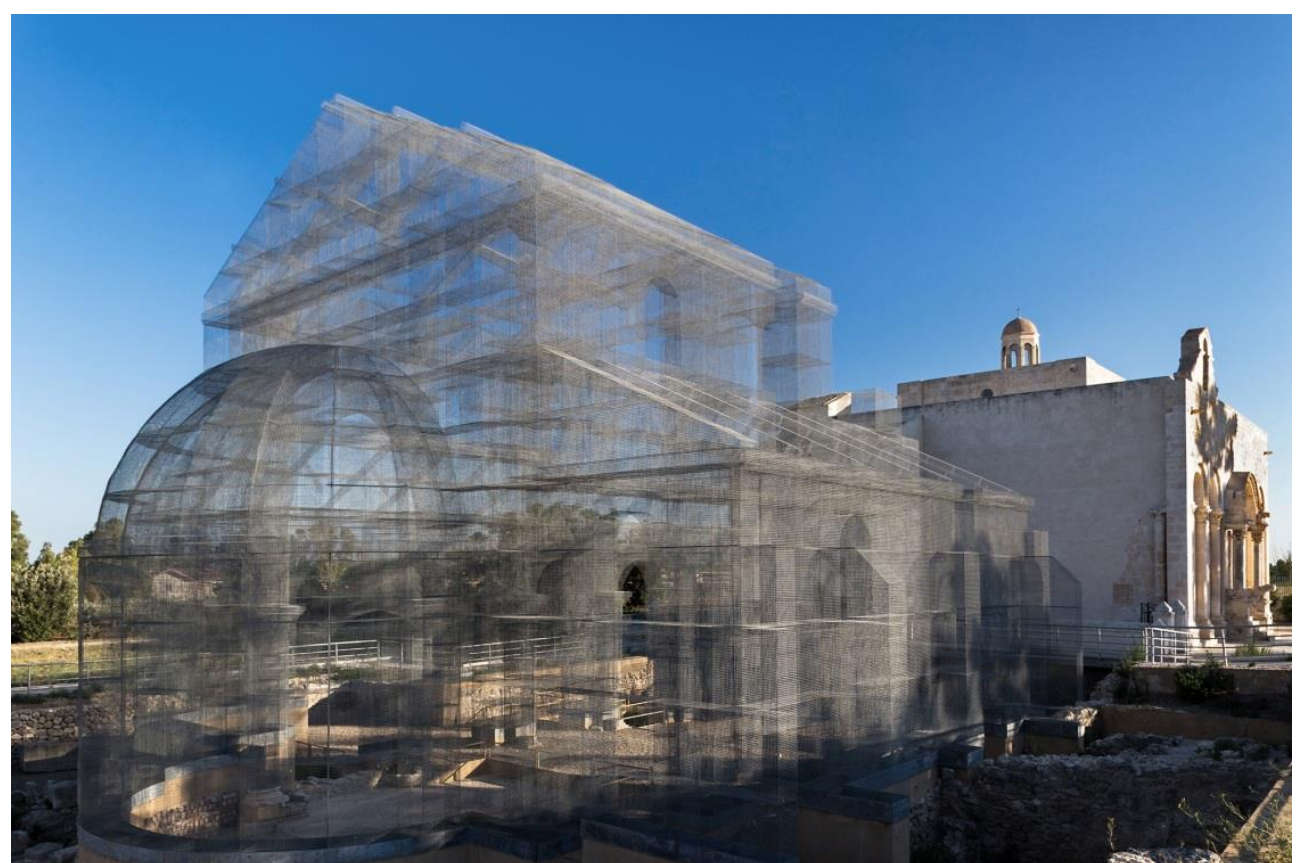

Figure 10. Edoardo Tresoldi, Siponto, View of the Artwork in relation to the Adjacent Romanesque Church

Source: Roberto Conte, 2016. 


\section{Acknowledgments}

I would like to express my sincere thanks to Prof. Giovanni Carbonara for his valuable advices. I also want to remember that this essay is the result of research funded by the European Union - European Regional Development Fund - PON Aim - Research and Innovation - International and Attraction mobility (20142020).

\section{Bibliography}

Amore, R., A. Pane and G. Vitagliano. Restauro, Monumenti e Città. Teorie ed Esperienze del Novecento in Italia. [Restoration, Monuments and Cities. Theories and Experiences of the Twentieth Century in Italy.] Napoli: Electa, 2008.

Andaloro, M. La Teoria del Restauro nel Novecento da Riegl a Brandi, Atti del Convegno Internazionale Di studi, Viterbo, 12-15 Novembre 2003 [The Theory of Restoration in the Twentieth Century from Riegl to Brandi, Proceedings of the International Conference of Studies, Viterbo, 12-15 November 2003.] Firenze: Nardini, 2006.

Baldini, U. Teoria del Restauro e Unità di Metodologia [Restoration Theory and Methodology Unit]. Firenze: Nardini, 1981.

Boito, C. "I Restauri in Architettura. Dialogo Primo." [Restorations in Architecture. First Dialogue.] In Questioni di Pratiche di Belle Arti. Milano: 1893.

Bonelli, R. "Restauro (il Restauro Architettonico.)" [The Architectural Restorarion.] In Enciclopedia Universale dell'Arte. Venezia-Roma: Istituto per la Collaborazione Culturale, 1963, XI.

Brandi, C. "Archeologia Siciliana." [Sicilian Archaeology.] In Bollettino dell'Istituto Centrale del Restauro (1956), 27-28. . Teoria del restauro [Theory of restoration]. Torino: Einaudi, 1977.

Calò Mariani, M. S. "L'Arte Medievale e il Gargano." [Medieval Art and the Gargano.] In La Montagna sacra, S. Michele, Monte Sant'Angelo, il Gargano. Foggia: Congedo, 1991, 56-72.

Carbonara, G. Trattato di Restauro Architettonico. [Treaty of Architectural Restoration.] Torino: Utet, 1996.

Casiello, S. La Cultura del Restauro. Teorie e Fondatori. [The Culture of Restoration. Theories and Founders.] Venezia: Marsilio, 1996.

Cazzato, V. Istituzioni e Politiche Culturali in Italia negli anni Trenta. [Cultural Institutions and Policies in Italy in the 1930s.] Roma: Istituto Poligrafico dello Stato, 2001.

Chiavoni, E., F. Porfiri and G. L. Tacchi. "La Rappresentazione dell'assenza: Reinterpretare la Storia Attraverso un Linguaggio Contemporaneo." [The Representation of Absence: Reinterpreting History through a Contemporary Language, Territories and Frontiers of Representation.] In Territori e Frontiere della Rappresentazione, Atti Del $39^{\circ}$ Convegno Internazionale dei Docenti delle Discipline della Rappresentazione (Napoli, 14-16 Settembre 2017.) Roma: Gangemi, 2017, 829-834.

Cristinelli, G. Fondamenti per una Dottrina del Restauro Architettonico [Basics for a Doctrine of Architectural Restoration]. Roma: Ginevra Bentivoglio, 2017.

De Felice, G. "Cathedrals in the Desert: A Review of Edoardo Tresoldi's Installation at Siponto, Italy." Public Archeology 15, no. 1 (2016): 59-61.

De Lucchi, M. “Contamination. Hybridisation.” Domus 1027 (September 2018): 38-39. 
Ezechieli, C. "Spazio e Materia. Conversazione con Edoardo Tresoldi. Labics, due Progetti per due Concorsi." [Space and Matter. Conversation with Edoardo Tresoldi. Labics, Two Projects for Two Competitions.] ioArch 13 (July 2019): 60-63.

Fabbri, M. "La Basilica Paleocristiana di Siponto: Nuove Acquisizioni." [The Early Christian Basilica of Siponto: New Acquisitions.] Vetera Christianorum 31 (1994): 189-196.

Franceschi, S. and L. Germani. Manuale Operativo per il Restauro Architettonico. Metodologie di Intervento per il Restauro e la Conservazione del Patrimonio Storico. [Operating Manual for Architectural Restoration. Methodologies of Intervention for the Restoration and Conservation of the Historical Heritage.] Roma: Tipografia del Genio Civile, 2005.

Galli, L. Restauro Architettonico: Letture dai Maestri. [Architectural Restoration: Readings from the Masters.] Milano: Hoepli, 2016.

Giorgi, E. "Edoardo Tresoldi, l'uomo che ha Stregato il Mondo (e Forbes) con le sue Cattedrali Metalliche." [Edoardo Tresoldi, the Man who has Bewitched the World (and Forbes) with his Metal Cathedrals.] In La Repubblica, 15 May 2017. Retrieved from: https://www.repubblica.it/cultura/2017/05/15/news/edoardo_tresoldi162340465/. [Accessed 20 May2020].

Giovannoni, G. Il Restauro dei Monumenti. [The Restoration of Monuments.] Roma: Cremonese, 1945.

Giuffreda, O. Antologia storico-Artistica di Siponto, Manfredonia, Monte Sant'Angelo. [Historical-Artistic Anthology of Siponto, Manfredonia, Monte Sant'Angelo.] San Marco in Lamis: CRSEC FG/29, 2005.

Grimoldi, A. Omaggio a Camillo Boito. [Tribute to Camillo Boito]. Milano: Franco Angeli, 1991.

Jonna, M. "Edoardo Tresoldi- Le Infinite Forme dell'Invisibile." [Edoardo Tresoldi- The Infinite Forms of the Invisible.] In Icon Design (November 2018), 112-119.

Lagagnara, C. Siponto - Archeologia di una Città Abbandonata nel Medioevo. [Siponto Archaeology of an Abandoned City in the Middle Ages]. Foggia: Grenzi, 2011.

Laurenti, M. C. Le Coperture delle Aree Archeologiche. Museo Aperto. [The Roofs of the Archaeological Sites. Open Museum.] Roma: Gangemi, 2006.

Longhi, R. "Restauri." [Restorations.] La Critica d'Arte 2 (1940).

Mairs, J. "Edoardo Tresoldi Uses Wire Mesh to Reconstruct Ancient Roman Church in Italy." In Dezeen, 6 april 2016. Retrieved from: https://www.dezeen.com/2016/04/ 06/edoardo-tresoldi-wire-mesh-installation-ancient-roman-church-italy/. [Accessed 20/05/2020].

Marconi, P. Materia e Significato. La Questione del Restauro Architettonico. [Matter and Meaning. The Question of Architectural Restoration.] Bari: Laterza, 1999.

Norberg-Schulz, C. Genius Loci. Milano: Electa, 1979.

Pellegrini, P. C. Manuale del Riuso Architettonico: Analisi ed Interventi Contemporanei per il Recupero degli Edifici. [Manual of Architectural Reuse: Analysis and Contemporary Interventions for the Recovery of Buildings.] Palermo: Flaccovio, 2018.

Pierotti, P. and A. Nonni. Dove l'arte Ricostruisce il Tempo. Il Parco Archeologico di Santa Maria di Siponto. Un Modello di Valorizzazione a Manfredonia. [Where Art Reconstructs Time. The Archaeological Park of Santa Maria di Siponto. A Model of Valorisation in Manfredonia.] Roma: PPAN - Comunicazione e Networking per il Costruito, 2016.

Riegl, A. "The Modern Cult of Monuments: Its Character and Origin." Oppositions 25 (Fall 1982): 21-51. 
Scarrocchia, S. Alois Riegl - Il Culto Moderno dei Monumenti. [Alois Riegl - The Modern Cult of Monuments.] Bologna: Nuova Alfa, 1990.

Stolfi, G. "Boito, gli Altri e il Moderno Pensiero sul Restauro." [Boito, the Others and Modern Thinking about Restoration.] In Quaderni dell'Istituto di Storia dell' Architettura. Saggi in onore di Renato Bonelli. Edited by C. Bozzoni, G. Carbonara and G. Villetti. Roma: Multigrafica, 1992, 935-942.

Ugolini, A. Ricomporre la Rovina [Recompose the Ruin]. Firenze: Alinea, 2010.

Vlad Borrelli, L. Conservazione e Restauro delle Antichità. Profilo Storico [Conservation and Restoration of Antiquities. An Historical Profile]. Roma: Viella, 2010.

Wong, L. Adaptive Reuse: Extending the Life of Buildings. Basel: Birkhäuser, 2017. 
